\title{
Дискуссия
}

\author{
Кураев Г.А., Войнов В.Б.
}

\section{Этнопсихофизиология. Перспективы становления}

В статье обсуждаются перспективы выделения в отдельное направление систем наук о человеке - этнопсихофизиологии. Своевременность $u$ актуальность исследования психофизиологических особенностей групп людей, связанных родством и компактно проживающих в специфических условиях на одной территории определяется тремя причинами. Во-первых, наличием, требующей подтверждения, гипотезы о том, что генотип и начиональный уклад жизни различных этнических групп определяют при своем сложном взаимодействии набор морфологических, физиологических и психологических свойств конкретного человека. Во-вторых, неразработанностью общих представлений о формировании, развитии и сохранении здоровья индивида в рамках отдельных этнических групп. В-третьих, отсутствием убедительных модельных представлений о механизмах, определяющих морфофункииональное и психофизиологическое своеобразие различных этнических групп.

Ключевье слова: психофизиология, этнос, индивид, наследственность, адаптация.

Полиэтничность и поликультурность современного российского общества, усиление в нем миграционных процессов выдвигают перед политологией, социологией, психологией и, в том числе, перед биологией комплекс теоретических и практических проблем. Рассматривая человечество в качестве единой системы взаимосодействующих личностей, следует ожидать доминирования интеграционных процессов, определяющих механизмы созревания этой общности. При этом интеграцию не следует понимать однозначно как путь размывания особенностей и формирования аморфной массы. Процессы созревания систем, проходя пути объединения, предполагают специализацию составляющих их 
компонентов, развитие частных особенностей. В данном случае идеализация развития межэтнических взаимодействий видится в объединении народов на основе общих экономических и политических задач при сохранении их психологического и культурного своеобразия, т.е. в сочетании тенденций интернационализма и национализма [12]. Реальная межнациональная интеграция в современном мире представляется в форме слияния, снятия специфических форм языка и культурных традиций, глубоко интегрированных в природные условия и историю народа, связанных с народным творчеством, традициями воспитания детей и т.д. [20]. Внимание привлекает, на пример, глубокая проработанность развития концепции национальной калмыцкой школы на базе «этнокультурной коннотации», т.е. на основе развития языковых знаков, базовых понятий, лежащих в основе национальной культуры $[21,22]$. При этом авторы подчеркивают важность развития толерантности в сфере межэтнических отношений, как основы плодотворной интеграции в рамках многонационального государства. Но, противоречия сохраняются... реальность или иллюзорность идей интеграции, при сохранении специфических этнических свойств. Несмотря на привлекательность представлений об объединении наций при сохранении этнического своеобразия, в последние годы реальная жизнь сотрясается межнациональными и межконфессиональными конфликтами, ростом различных форм противостояния.

Несомненно, одной из сложнейших является проблема соотношения объединяющих общегосударственных факторов с локальными особенностями: исторически устойчивым укладом жизни народов, их специфическими культурными и даже психическими особенностями. Годы нерациональной национальной политики и современное государственное строительство на территории бывшего СССР породили целый ряд серьезных проблем, связанных с потерей населением основ своей национальной идентификации. При этом следует отметить, что палитра обсуждения национальных проблем в настоящее время весьма широка, но очевидно доминирование волюнтаристских, упрощенных подходов, опирающихся, как правило, на силовые методы. Возможно ли естественнонаучное обоснование перспектив интегративных шагов?

Вероятно, одним из самых пестрых и сложных регионов Росси является ее Южный регион, более 55 народов и этнических групп, более чем 100 национальных меньшинств, его населяющих, отличаются языками, диалектами, антропологической принадлежностью, этногенезом, верованиями, культурой, 
менталитетом и т.д. $[11,25]$. Умаев подчеркивает, что исторический анализ позволяет отметить уникальную для Евразии, несмотря на отмеченную выше сложность и пестроту национального устройства, многовековую внутреннюю толерантность народов Кавказа [26]. Тем не менее, для новейшей истории региона, по мнению Н.В. Тузова, характерен расцвет таких специфических проявлений антагонизма как межклановая, межродовая, межтейповая враждебность [25]. Очевидно, что большинство социальных проблем находит свои корни в неабсолютных политических и экономических решениях, в групповых и индивидуальных амбициях в отношении власти и денег.

Основным компонентом социальных процессов является личность человека, причем человек выступает не только как объект социальных преобразований, но и как активный субъект, обладающий комплексом индивидуально-типологических биологических и психических свойств. Устойчивое словосочетание «индивидуально-типологические свойства», широко использующееся в психологической и физиологической литературе отражает двойственный характер личности человека, c одной стороны еe уникальную морфофункциональную сущность, как функцию генетического своеобразия и конкретного жизненного опыта. С другой стороны, личность человека в значительной степени типизирована в отношении устойчивых биологических и базовых психофизиологических свойств, включающих такие широко обсуждаемые понятия как тип темперамента [23], психический архетип [27], этнические константы [19] и т.д. В отечественной психологии «личность» занимает одно из лидирующих мест, но, однако, при разработанности подходов к исследованию ее структуры, современные взгляды на факторы, определяющие процессы ее формирования имеют, по-прежнему, в значительной степени социально-экономический, политизированный характер [2]. В лучшем случае речь идет об этнокультурных влияниях, проявляющихся, в частности, в характере психопатологической симптоматики [10]. Однако, при этом сегодня достаточно очевидным представляется наличие у человека не только общечеловеческих видовых свойств, но и сознательных, и духовных особенностей, имеющих отношение к популяционным, в том числе к этническим и родовым свойствам. 
Современная психофизиология отмечает, что природное в человеке, синонимичное наследуемому, это, прежде всего, нейродинамические свойства его центральной нервной системы, определяющие особенности процессов познания и темпераментальные свойства. Наиболее полно признаки наследственности свойств центральной нервной системы исследованы в рамках отечественной дифференциальной психофизиологии, в первую очередь, с использованием параметров суммарной биоэлектрической активности мозга $[8,24]$. Значительный объем исследований посвящен выявлению стилевых форм мыслительной деятельности, обусловленных, в частности, паттернами функциональной межполушарной асимметрии мозга $[6,17]$. Достаточно широко обсуждаются проблемы, связанные с генетикой специфических форм поведения. Фундаментальность этих работ подтверждается значительным числом публикаций, как отечественных, так и зарубежных, охватывающих феномены поведения животных [16] и интеллектуальные способности человека [28]. Несмотря на актуальность подобных исследований и научный интерес к проблематике, сам факт работ в этой области порождает сегодня целый комплекс этических и правовых проблем, и попрежнему является крайне щепетильным в отношении социальных и политических отношений [5].

Современная отечественная психология вслед за Л.С. Выготским [7] и А.Н. Леонтьевым [18] широко развивает центральный тезис русской культурно-исторической школы о том, что структура и развитие психических процессов человека порождаются исторически развивающейся практической деятельностью, a известный отечественный генетик Н.П. Дубинин, работая с материальными факторами живого, писал о становление черт личности как функции истории человечества, которая определяет и науку, и мораль, и культуру. Тем не менее, еще в шестидесятых годах прошлого века Л.С. Выготский отмечал сложное взаимодействие влияющих на формирование психики ребенка «естественных», а не только «культуральных» и «социальных» факторов [7]. И в этих двух мнениях можно видеть очевидный дуализм ситуации, которая сохраняется и по настоящее время.

Некоторые авторы придерживаются точки зрения, что базовые свойства личности человека, наряду с особенностями его биологических свойств, определяются в широком смысле экологическими факторами. Экологические факторы участвуют в формировании антропобиогеоценоза как совокупности биологических 
свойств и демографических характеристик, определяющих адаптационные возможности популяции человека [14]. К подобным же заключениям приходят и исследователи группы академика Т.И. Алексеева [1], в течение ряда лет исследующие экологию и этногенез населения Центрально-Азиатского и Северо-Восточного регионов Евразии. Л.Н.Гумилев утверждает, что процессы этногенеза определяются тремя ведущими факторами: историей, геоклиматическими факторами, генетикой [9]. При этом автор подчеркивает, что этнос, являясь динамическим образованием, имеющим неповторимую внутреннюю структуру и оригинальный стереотип поведения, не может упрощаться до социологического, биологического, или географического явления. Несмотря на глубину представлений автора о корнях формирования этноса нельзя в полной мере согласиться с тем, что он удаляет из контекста анализа своеобразия этноса такие базовые с нашей точки зрения параметры, как генотип и психотип, а на первый план выводит некоторую гуманистическую конструкцию - «культурные традиции». И более того, анализируя значимость действующих на формирование этноса сил, автор очень мягко приводит к тому, что природные силы (биологические, геоклиматические и т.д.) - это не столько фактор, сколько лишь фон этнических модификаций.

Групповые особенности людей распространяются и на такую биосоциальную категорию, как здоровье (здоровье популяции, общества, здоровье человека). Здоровье популяции определяется как результирующая процесса социально-исторического развития биологической и психосоциальной жизнедеятельности населения в ряду поколений и в конкретных условиях. Качество здоровья населения непосредственно связано с его способностью эффективно приспосабливаться к условиям проживания (геоклиматическим, биоценотическим, политическим), формируя стереотипы поведения и психические свойства, способы преодоления достаточно ограниченного круга стрессирующих факторов, формируя оптимальный образ жизни. А.Б. Коган отмечал важность экологического подхода для разработки ряда проблем гигиены и медицины, перспективность развития такого направления как «география здоровья» [15].

Современная этнопсихология опирается на представления о константности этнической культуры как совокупности оптимальных моделей поведения, в значительной степени формирующихся в процессе адаптогенеза этноса [19]. Очевидно, что в данном контексте речь идет не только об устойчивых формах поведения, своеобразии 
языка и искусства, но и определенных биологических константах, определяющих своеобразие нейродинамических свойств центральной нервной системы, когнитивных особенностей личности, пищевого поведения и т.д.

Достижения современной психофизиологии позволяют утверждать, что «национальный характер» имеет объективные черты, определяющиеся не только социокультурными факторами. Накоплен достаточный объем сведений, позволяющих говорить о специфических особенностях морфологии, физиологии, психики группы людей (этноса, этнической группы), проживающей достаточно автономно в некоторых специфических экологических условиях, в том числе, и в рамках определенных социокультурных стереотипов.

Таким образом, сформировавшийся социальный запрос с одной стороны и имеющий место существенный объем теоретических наработок и эмпирических данных в отношении наследуемости базовых свойств нервной системы человека и архетипических поведенческих форм определяют необходимость формирования нового научного направления человекознания «этнопсихофизиология». Психофизиологические подходы актуальны в самых различных областях: от фундаментальных размышлений о дуализме духа и тела, до практических задач обеспечения здоровья и борьбы с функциональными расстройствами и заболеваниями, до решения проблем сохранения и развития крупиц национальной культуры, решения проблем социально-политических отношений. В настоящее время нет исследований, раскрывающих индивидуальнотипологические свойства личности как компонента определенной этнической группы. Практически отсутствуют работы, включающие анализ нейрофизиологических механизмов, определяющих психические особенности человека как представителя определенного этноса. Основным и перспективным направлением развития этнопсихофизиологии является исследование специфических особенностей возрастной периодизации и детерминации зон ближайшего развития в становлении физиологии и психики детей. В России невозможно найти школу с мононациональным составом учащихся, но, тем не менее, все они обучаются по единому учебному плану, в силу чего дети различных этнических групп оказываются изолированными от своей культуры [3, 21, 22]. В образовательном процессе, как правило, не учитываются психофизиологическое своеобразие представителей разных этносов, к примеру, образность или аналитичность первичных мыслительных процессов. 
В качестве методического арсенала этнопсихофизиологии видится широкий спектр средств современной антропологии, физиологии, психологии, психофизиологии. Целесообразно проведение описания своеобразия особенностей формирования и функционирования ведущих систем организма: центральной нервной, сердечно-сосудистой, дыхательной; высшей нервной деятельности (соматотип, типологические свойства систем, профиль функциональной межполушарной асимметрии мозга, структура личности и психологические свойства).

В частности, целесообразность развертывания подобных исследований определяется несколькими основными причинами.

Во-первых, наличием, требующей подтверждения, гипотезы о том, что генотип и национальный уклад жизни различных этнических групп, проживающих, на пример, на территории Южного Федерального округа РФ, определяют при своем сложном взаимодействии своеобразный набор морфологических, физиологических и психологических свойств конкретного человека, специфику возрастной динамики онтогенеза.

Во-вторых, неразработанностью общих представлений о формировании, развитии и сохранении здоровья индивида в рамках обособленных этнических групп, проживающих продолжительное время в конкретных экологических условиях и испытывающих действие типичных лимитирующих факторов. Развитие этого направления базируется на теоретических представлениях о нежестком, не абсолютном характере категории «здоровье человека». Качественные и количественные параметры здоровья зависят от устойчивых наследственных факторов, психофизиологических особенностей индивида, от этапа онтогенеза, от специфики актуальных потребностей и социальной роли, которую он исполняет.

В-третьих, отсутствием убедительных модельных представлений о механизмах, определяющих морфофункциональное и психофизиологическое своеобразие различных этнических групп Южного федерального округа РФ, что существенно сказывается на организации адекватных мер по управлению здоровьем, и разработке «регионального компонента» учебных планов образовательных учреждений.

Есть все основания надеяться, что продолжительная, кропотливая работа в рамках этнопсихофизиологии принесет 
положительные плоды для организации разумной политической, экономической, педагогической деятельности, направленной на межнациональную интеграцию.

\section{Литература}

1. Алексеев Т.И. Экология и этногенез населения Северной Евразии. Центрально-Азиатский и Северо-Восточный регионы // Отчет по программе Фундаментальных исследований Президиума РАН «Этнокультурное взаимодействие в Евразии» за 2003 год. Москва, 2004. C.39-40.

2. Ананьев Б.Г. Социальные ситуации развития личности и ее статус // Избранные психологические труды. Том.1. М.: Педагогика, 1980. C.124-136.

3. Белозерцев Е.П. О национально-государственном образовании в России // Педагогика. 1998. №3. С.14-19.

4. Бондаренко О.Я. Этническая прогностика: возможно ли её создание? // Современная этнопсихология / под ред. А.Е.Тараса. М.: Харвест, 2003. 368 с.

5. Борисов Ю. Генетика поведения человека: этический контекст // Человек. 2003. №2. С. 8-17.

6. Брагина Н.Н., Доброхотова Т.А. Функциональные асимметрии человека. М.: Медицина, 1981. 267 с.

7. Выготский Л.С. Развитие высших психических функций. - М.: Издательство Академии Педагогических Наук, 1960. 245 с.

8. Гавриш Н.В., Равич-Щербо И.В., Шибаровская Г.А., Шляхта Н.Ф. Индивидуальная ЭЭГ, ее онтогенетическая стабильность и ее генетическая обусловленность // Мозг и психическая деятельность. М.: Наука, 1984. С.125-137.

9. Гумилев Л.Н. Этногенез и биосфера Земли. М.: Азбука, 2003. $608 \mathrm{c}$.

10. Гурвич И.Н. Социально-психологические факторы здоровья // Психология здоровья. СПб.: Изд-во С.-Петерб.ун-та, 2000. С.361-404.

11. Добаев И.П. Предисловие // Евразийский проект: Кавказский вектор. Южнороссийское обозрение. 2005. Вып.30. С. 5-10.

12. Дугин А.Г. Геополитика как эффективный метод современной Российской политической теории и практики // Евразийский проект: Кавказский вектор. Южнороссийское обозрение. 2005. Вып.30. С. 11-30.

13. Кармаев Н.А. Современные проблемы экологии человека // Отчуждение человека в перспективе глобализации мира. Сборник философских статей. Выпуск I / Под ред. Маркова Б.В., Солонина Ю.Н., Парцвания В.В. Изд. «Петрополис», Санкт-Петербург, 2001. С.87-100.

14. Коган А.Б. О значении экологических факторов в формировании свойств анализаторных систем головного мозга // Эволюция, экология и мозг. Л.: Медицина, 1972. С.29-36. 
15. Крушинский Л.В. Биологические основы рассудочной деятельности. М.: Изд-во МГУ. 1979, 270 с.

16. Кураев Г.А. Психофизиологические корреляты взаимодействия полушарий головного мозга в онтогенезе // XVIII съезд Физиологического общества им. И.П.Павлова. Тезисы докладов. Казань. 2001. С.536-537.

17. Леонтьев А.Н. Проблемы развития психики. М.: Изд. МГУ, 1981. $584 \mathrm{c}$.

18. Лурье С.В. Психологическая антропология: История, современное состояние, перспективы. Екатеринбург. Деловая книга. 2003. $623 \mathrm{c}$.

19. Историческая этнология. М., Аспект Пресс, 1997. 448 с.

20. Очирова Н.Г. Этнокультурное взаимодействие народов Юга России // Отчет по программе Фундаментальных исследований Президиума РАН «Этнокультурное взаимодействие в Евразии» за 2003 год. Москва, 2004. C.65-66.

21. Панькин А.Б. Этнокультурный парадокс современного образования. Волгоград «Перемена», 2001. 446 с.

22. Панькин А.Б. Формирование этнокультурной личности. М. ООО «Большая медведица», 2004. 272 с.

23. Русалов В.М. О природе темперамента и его месте в структуре индивидуальных свойств человека // Вопросы психологии. 1985, №1. С.1933.

24. Русинов В.С., Гриндель О.М., Болдырева Г.Н., Вакар Е.М. Биопотенциалы мозга человека. М.: Медицина, 1987. 256 с.

25. Тузов Н.В. Северный Кавказ: этнос, религия, политика. 2003. http://humanities.edu.ru/db/msg/48641

26. Умаев У.М. Этнический состав Северного Кавказа. Проблемы толерантности в России // Путь Востока. Культурная, этническая и религиозная идентичность. Материалы VII Молодежной научной конференции по проблемам философии, религии, культуры Востока. Серия "Symposium". Выпуск 33. - СПб.: Санкт-Петербургское философское общество, 2004. С.36-39.

27. Юнг К.Г. Психологические типы. М.: Алфавит, 1992. 348 с.

28. Geus E.J.C. de, Wright M.J., Martin N.G., Boomsmal D.I. Genetics of Brain Function and Cognition // Behavior Genetics. 2001. Vol. 31, №6. P.489-495. 